Keywords: Saltstone

TCLP

Retention: Permanent

\title{
Saltstone Processing Facility Transfer Sample
}

\author{
A.D. Cozzi \\ M.M. Reigel
}

August 2010

Savannah River National Laboratory Savannah River Nuclear Solutions Aiken, SC 29808

Prepared for the U.S. Department of Energy under contract number DE-AC09-08SR22470.

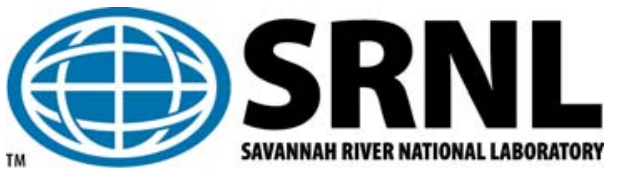


SRNL-STI-2010-00360

Revision 0

\section{DISCLAIMER}

This work was prepared under an agreement with and funded by the U.S. Government. Neither the U.S. Government or its employees, nor any of its contractors, subcontractors or their employees, makes any express or implied:

1. warranty or assumes any legal liability for the accuracy, completeness, or for the use or results of such use of any information, product, or process disclosed; or

2. representation that such use or results of such use would not infringe privately owned rights; or

3. endorsement or recommendation of any specifically identified commercial product, process, or service.

Any views and opinions of authors expressed in this work do not necessarily state or reflect those of the United States Government, or its contractors, or subcontractors.

\section{Printed in the United States of America \\ Prepared for \\ U.S. Department of Energy}




\section{REVIEWS AND APPROVALS}

AUTHORS:

A.D. Cozzi, Engineering Process Development

Date

M.M. Reigel, Engineering Process Development

Date

TECHNICAL REVIEW:

R.E. Eibling, Engineering Process Development

Date

APPROVAL:

A.B. Barnes, Manager

Date

Engineering Process Development

S.L. Marra, Manager

Date

Environmental \& Chemical Process Technology Research Programs

J.E. Occhipinti, Manager

Date

Waste Solidification Engineering 


\section{EXECUTIVE SUMMARY}

On May 19, 2010, the Saltstone Production Facility inadvertently transferred 1800 gallons of untreated waste from the salt feed tank to Vault 4. During shut down, approximately 70 gallons of the material was left in the Saltstone hopper. A sample of the slurry in the hopper was sent to Savannah River National Laboratory (SRNL) to analyze the density, $\mathrm{pH}$ and the eight Resource Conservation and Recovery Act (RCRA) metals. The sample was hazardous for chromium, mercury and $\mathrm{pH}$. 


\section{TABLE OF CONTENTS}

LIST OF TABLES




\section{LIST OF TABLES}

Table 3-1. Concentration of the eight RCRA metals in the hopper slurry sample compared to the 1Q10 Tank 50 WAC results and the RCRA limits.

\section{LIST OF FIGURES}

Figure 1-1. Flow diagram from the SFT to Vault 4................................................................. 1

Figure 3-1. Hopper slurry sample after settling for approximately 20 minutes. ........................... 2

Figure 3-2. Hopper slurry sample after settling for $20 \mathrm{~min}$ (a) during ......................................... 3 


\section{LIST OF ABBREVIATIONS}

$\begin{array}{ll}\text { AA } & \text { Atomic Absorption } \\ \text { AD } & \text { Analytical Development } \\ \text { ICP-ES } & \text { Inductively Coupled Plasma - (atomic)Emission Spectroscopy } \\ \text { RCRA } & \text { Resource Conservation and Recovery Act } \\ \text { SFT } & \text { Salt Feed Tank } \\ \text { SRNL } & \text { Savannah River National Laboratory } \\ \text { SPF } & \text { Saltstone Processing Facility } \\ \text { TCLP } & \text { Toxic Characterization Leaching Procedure }\end{array}$




\subsection{Introduction}

On May 19, 2010, the Saltstone Processing Facility (SPF) inadvertently transferred approximately 1800 gallons of untreated low-level salt solution from the salt feed tank (SFT) to Cell $\mathrm{F}$ of Vault 4. The transfer was identified and during safe configuration shutdown, approximately 70 gallons of SFT material was left in the Saltstone hopper. After the shutdown, the material in the hopper was undisturbed, while the SFT has received approximately 1400 gallons of drain water from the Vault 4 bleed system [1]. The drain water path from Vault 4 to the SFT does not include the hopper (Figure 1); therefore it was determined that the material remaining in the hopper was the most representative sample of the salt solution transferred to the vault.

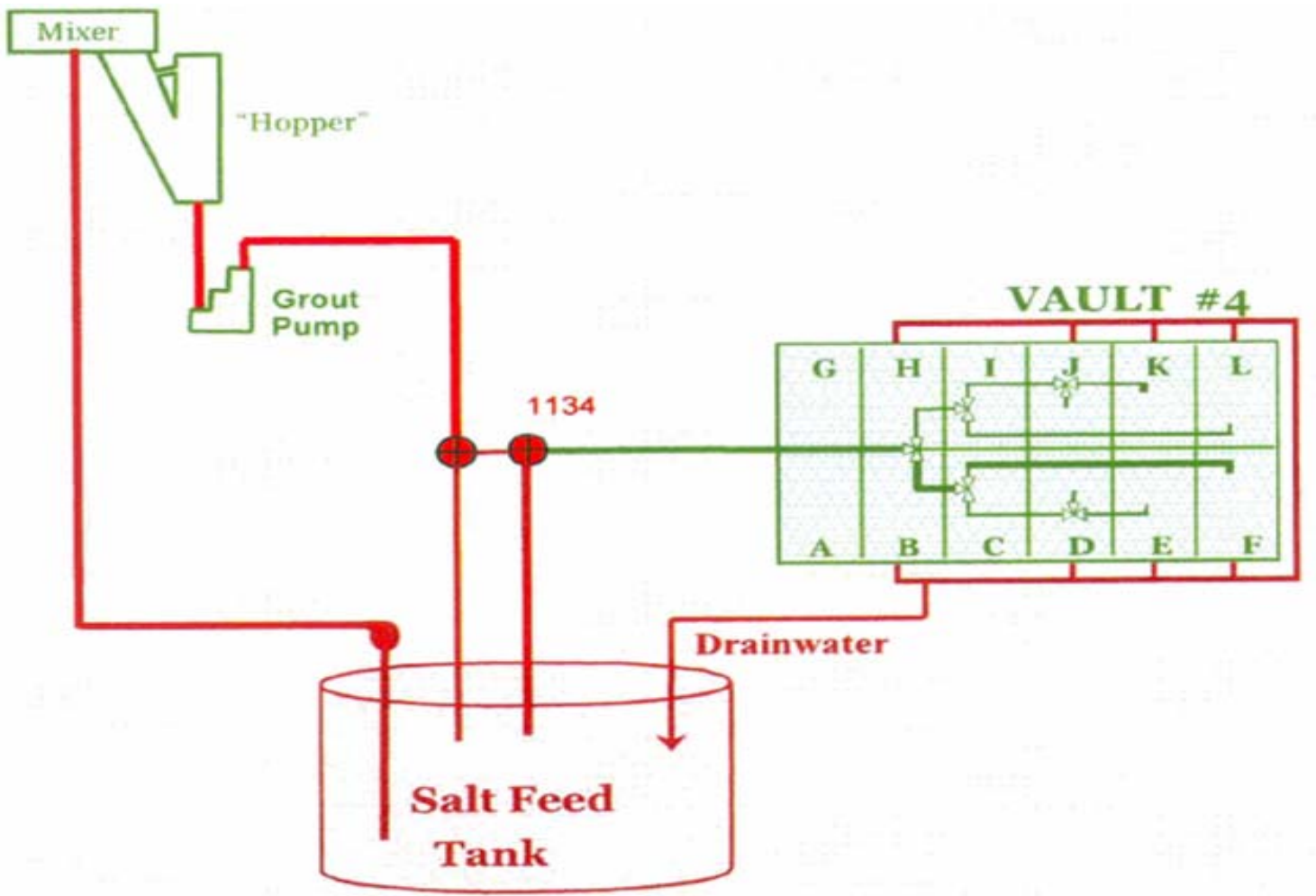

Figure 1-1. Flow diagram from the SFT to Vault 4.

Savannah River National Laboratory (SRNL) was asked to analyze the liquid sample retrieved from the hopper for $\mathrm{pH}$, the eight Resource Conservation and Recovery Act (RCRA) metals (As, $\mathrm{Ba}, \mathrm{Cd}, \mathrm{Cr}, \mathrm{Pb}, \mathrm{Hg}$, Se, and $\mathrm{Ag}$ ) and density to determine the hazardous nature of the material inadvertently transferred to Vault 4. The detection limits must support characteristic determination of hazardous waste per 40CFR261.24 [2]. 


\subsection{Experimental Procedure}

The slurry samples collected from the Saltstone hopper arrived at SRNL on May 24, 2010 in two $80 \mathrm{~mL}$ and one $100 \mathrm{~mL}$ steel samplers. The extremity dose rate of the large sample was 8 $\mathrm{mrem} / \mathrm{hr}$, therefore the samples were worked in the SRNL shielded cells. The three samples were composited in a $500 \mathrm{~mL}$ polyethylene bottle. The solids were allowed to settle and supernate was used to rinse the steel samplers to recover remaining solids.

A large slurry pipette was used to obtain a slurry sample for digestion using mixed acid for Inductively Coupled Plasma - (atomic) Emission Spectroscopy (ICP-ES) and atomic absorption (AA) analysis. The final sample dilution volume was $50 \mathrm{~mL}$. Approximately $3 \mathrm{~mL}$ of slurry was used to determine the density of the sample.

The remaining sample in the $500 \mathrm{~mL}$ bottle was allowed to settle in order to determine the $\mathrm{pH}$ of the supernate using both a $\mathrm{pH}$ probe and $\mathrm{pHydrion}$ microfine $\mathrm{pH}$ paper.

\subsection{Results and Discussion}

The sample received from the Saltstone hopper was analyzed visually while obtaining sample aliquots and while the sample was allowed to settle. It was observed that the sample contains solids that settle in approximately 20 minutes (Figure 3-1). There is a floating layer on top of the supernate during settling and disperses when the sample is agitated (Figure 3-2).

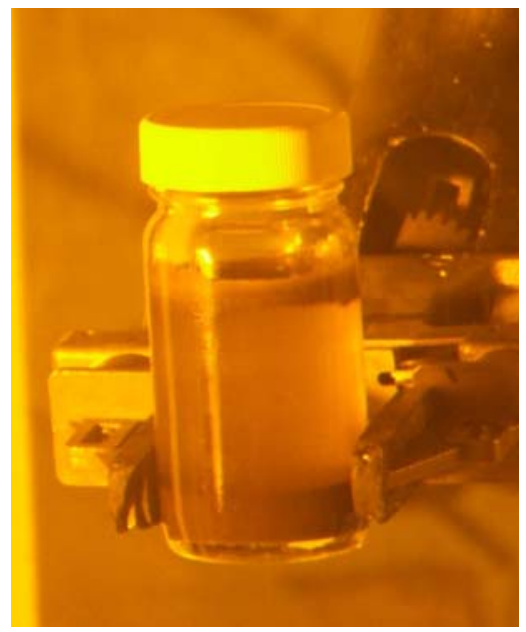

Figure 3-1. Hopper slurry sample after settling for approximately 20 minutes. 

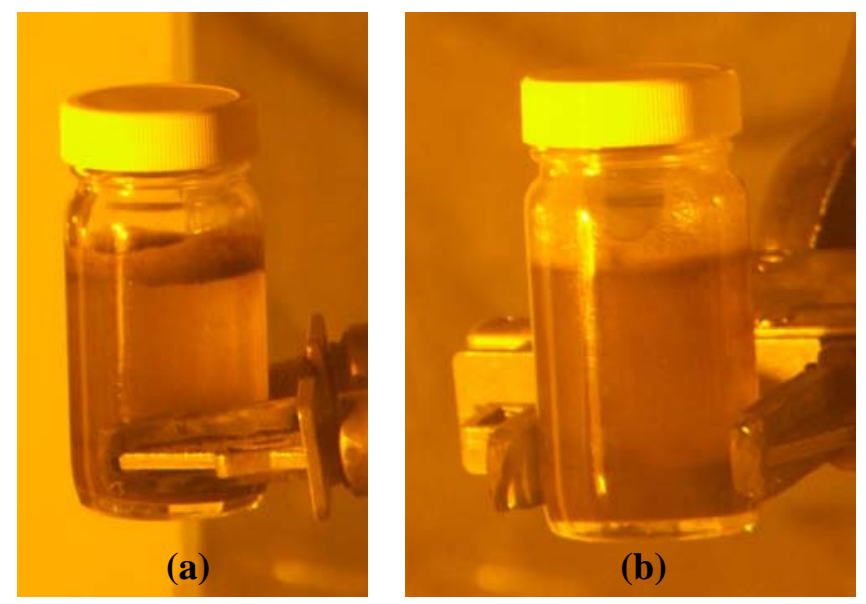

Figure 3-2. Hopper slurry sample agitated after settling for 20 min to (a) break up floating later and (b) incorporate it into the sample.

\subsection{RCRA Metals}

The slurry samples were analyzed for the eight RCRA metals to determine the hazardous nature of the sample transferred to Vault 4. As reported in Table 3-1, chromium and mercury are above the RCRA limit.

Table 3-1. Concentration of the Eight RCRA metals in the Hopper Slurry Sample.

\begin{tabular}{|c|c|c|c|}
\hline & Method & $\begin{array}{c}\text { Hopper Sample } \\
\text { mg/L }\end{array}$ & $\begin{array}{c}\text { RCRA Toxicity } \\
\text { Limit }^{\mathbf{a}} \mathbf{~ m g / L}\end{array}$ \\
\hline $\mathbf{A g}$ & ICP-ES & 0.770 & 5 \\
\hline $\mathbf{B a}$ & ICP-ES & 8.94 & 100 \\
\hline $\mathbf{C d}$ & ICP-ES & 0.362 & 1 \\
\hline $\mathbf{C r}$ & ICP-ES & 47.937 & 5 \\
\hline $\mathbf{P b}$ & ICP-ES & 3.044 & 5 \\
\hline $\mathbf{A s}$ & AA & 1.149 & 5 \\
\hline $\mathbf{S e}$ & AA & 0.700 & 1 \\
\hline $\mathbf{H g}$ & AA & 87.6 & 0.2 \\
\hline
\end{tabular}

a. SCHWMR R.61-79.261.24(b) “Characteristic of Toxicity.”

\subsection{Density and $\mathrm{pH}$}

The density of the slurry sample is $1.0354 \mathrm{~g} / \mathrm{mL}$ at $21.1{ }^{\circ} \mathrm{C}$. A pH probe was initially used to measure the $\mathrm{pH}$ of the supernate and read a $\mathrm{pH}$ of 12.53 . However, when the sample was retested, the probe was not able to get an accurate measurement, even when the buffers were used. It was determined that the high molarity of the sample affected the performance of the $\mathrm{pH}$ probe. Narrow range $\mathrm{pH}$ paper $(12.4-13.9)$ was used to determine the $\mathrm{pH}$ of the sample. Triplicate strips indicated a $\mathrm{pH}$ of $12.5,12.6$ and 12.6. Therefore the $\mathrm{pH}$ of the transferred sample is $12.6 \pm$ 1 . The regulatory limit is 12.5 . However, due to the error associated with the $\mathrm{pH}$ paper, it cannot be stated conclusively that the sample exceeds this limit. 


\subsection{Conclusions}

The untreated waste inadvertently transferred from the SFT to Vault 4 was toxic for chromium and mercury. In addition, the $\mathrm{pH}$ of the sample is at the regulatory limit. Visually inspecting the sample indicates solids present in the sample. 
Revision 0

\subsection{References}

1. Cozzi, A.D., Reigel, M.M., "Task Technical and Quality Assurance Plan for Analysis of Grout Hopper Liquid Sample,” SRNL-RP-2010-01025, June 2010.

2. Staub, A.V. "Analysis of Grout Hopper Liquid Sample,” HLW-SSF-TTR-2010-0002, May 2010. 